\title{
Lean Manufacturing: Efficiency improvement application in multi-product area of the Aerospace Industry
}

\section{Manufactura esbelta: Aplicación de mejora de la eficiencia en área multiproducto de la Industria Aeroespacial}

CANO-CARRASCO, Adolfo†*, FORNÉS-RIVERA, René Daniel, VÁSQUEZ-TORRES, María del Carmen and GUERRERO-PORTILLO, Arlene Amalia

Instituto Tecnológico de Sonora

ID $1^{\text {st }}$ Author: Adolfo, Cano-Carrasco / ORC ID: 0000-0002-3392-3667, Researcher ID Thomson: G-5035-2018, arXiv Author ID: adolfo.cano, CVU CONACYT ID: 266064

ID $1^{\text {st }}$ Co-author: René Daniel, Fornés-Rivera / ORC ID: 0000-0002-7438-0056, Researcher ID Thomson: G-3906-2018, arXiv Author ID: rene_fornes, CVU CONACYT ID: 280435

ID $2^{\text {nd }}$ Co-author: María Del Carmen, Vásquez-Torres / ORC ID: 0000-0003-0938-4955, Researcher ID Thomson: X-21042018, CVU CONACYT ID: 286266

ID $3^{\text {rd }}$ Co-author: Arlene Amalia, Guerrero-Portillo / ORC ID: 0000-0002-7967-5777

DOI: $10.35429 / J R D .2021 .20 .7 .13 .20$

Received March 27, 2021; Accepted June 30, 2021

\begin{abstract}
This research addresses the problem of leveling workloads in a multi-product final assembly area. In which it was found that $27.4 \%$ of the time is used for set up and the current distribution presents areas of opportunity. The target was to implement improvement actions to make use of resources more efficient in the production process in the aforementioned area through Lean Manufacturing tools. The results obtained consist of eight products generated with the support of lean manufacturing support tools such as SMED, Workload Balancing and MUDA waste identification, achieving important results among which productivity in the area stands out from $109 \%$ to $125 \%$, as well as a reduction in set-up time from $17 \mathrm{~min}$ to 4.4 $\min$.
\end{abstract}

Lean, Productivity, Kaizen, Manufacturing

\begin{abstract}
Resumen
Esta investigación aborda el problema de nivelar cargas de trabajo, en un área de ensamble final de multiproducto. En la cual se encontró que un $27.4 \%$ del tiempo es utilizado para set up y la distribución actual presenta áreas de oportunidad. El objetivo fue implementar acciones de mejora para eficientar el uso de los recursos en el proceso de producción dicha área a través de herramientas de Manufactura Esbelta. Los resultados obtenidos consisten de ocho productos generados con el apoyo de las herramientas de soporte de la manufactura esbelta tales como SMED, Balanceo de cargas de trabajo, e identificación de desperdicios MUDA, logrando importantes resultados entre los que sobresale una productividad en el área que va de 109 a $125 \%$, así como una reducción del tiempo de set up de 17 a 4.4 min.
\end{abstract}

Esbelta, Productividad, Kaizen, Manufactura

Citation: CANO-CARRASCO, Adolfo, FORNÉS-RIVERA, René Daniel, VÁSQUEZ-TORRES, María del Carmen and GUERRERO-PORTILLO, Arlene Amalia. Lean Manufacturing: Efficiency improvement application in multi-product area of the Aerospace Industry. Journal of Research and Development. 2021. 7-20: 13-20

$\dagger$ Researcher contributing as first author. 


\section{Introduction}

Sonora has 53 manufacturing companies for blades and components for turbines and wind motors. This entity stands out due to the unique activities that are carried out in it, such as die casting, lost wax and sand mold, as well as heat and surface treatments. (De la Madrid, s/f).

The level of Lean Manufacturing Implementation in the maquiladora industry of Hermosillo and Guaymas-Empalme, Sonora (Piña et al., 2018) presents 14 common practices: level production, continuous flow, product quality, continuous improvement, order and cleanness, process control, lead time reduction, standardization, delivery on time, flexible production system, line balancing, direct personnel training, adherence to the production plan and customer satisfaction. Likewise, benefits are consequently reported in the areas of increased productivity, scrap reduction, cost reduction in quality, inventories, customer guarantee, raw material, improvement in deliveries on time, among others. (Monge et al., 2013).

The company under study manufactures electrical connectors, coaxial cables, fiber optic cables and communication antennas, its main customers are Boeing Company, Airbus S.E., Embraer S.A. and Safran Aircraft Engines (PRO MÉXICO, 2016). The object under study is the area of Final Assembly "Coaxial, Packaging and Others"; this has the objective of assembling a great variety of coaxial connectors, accessory packaging, installation of screws in rails and the elaboration of other varied products.

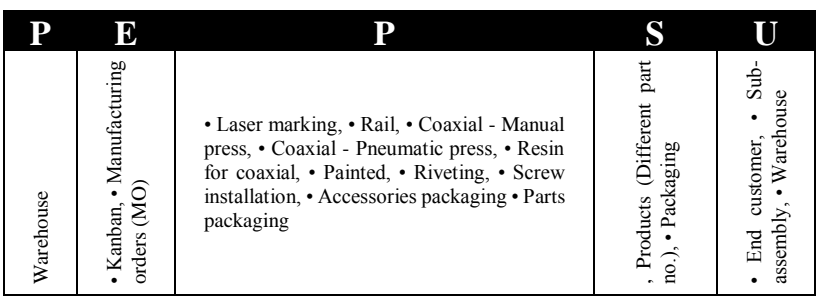

Table 1 PEPSU diagram of the final assembly area

Regarding personnel, the number of necessary operators has not been established, nor their leveling of workloads. There are 9 operators on shift 1, 6 on shift 2 and a leader. The times of change and preparation of the "laser marking" bottleneck, is approximately $3 \mathrm{hrs}$ causing less production and capacity.

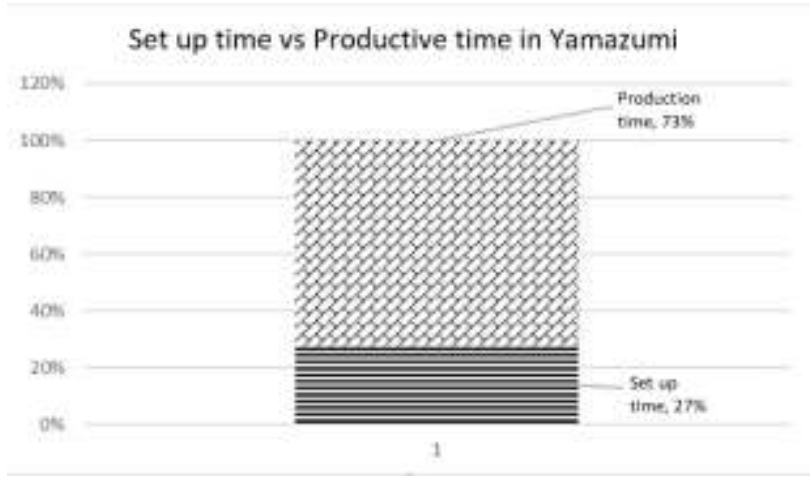

Figure 1 Current situation of laser marking set up times

In figure 1 the time required to set up on average is an approximate value of $8 \mathrm{~min} /$ order, the company has 11 hours of production time, of which $27 \%$ is to set up and $73 \%$ to produce. Most of the operations start with laser marking and there are crossings and setbacks in the production process.

Based on what has been described, it was detected that there is no balance that allows operators to have a leveled work load, nor to work at a constant pace. The problem has been defined as: "The area of final assembly Coaxials, Packaging and others presents deficiencies in the use of human resources, time and space in the production process."

\subsection{Objective}

Implement improvement actions to make the use of resources more efficient in the production process through Lean Manufacturing.

\section{Theoretical framework}

Lean manufacturing can be defined as a combination of multiple tools to help eliminate activities that do not add value to the product, service and/or process by increasing the value of each activity, aiming to eliminate or reduce waste and improve operations. (García-Alcaraz, Maldonado-Macías, \& Cortes-Robles, 2014). Womack defines lean production as a system that creates added value using less of each input, which is based on the Japanese concept of waste, hence the definition of waste is conceived as anything that requires more than the minimum of resources necessary to create products with value and high quality (Womack \& Jones, 1990). 
Lean Manufacturing seeks to reduce or eliminate waste in a production system in which the human element can be involved (Rahman, Sharif, \& Esa, 2013) (Manzouri, Ab-Rahman, Zain, \& Jamsari, 2014). In other words, the main intention of the Lean approach is to reduce cost, increase quality, maximize the product contribution margin and value for the customer or end user. (Nallusamy, 2020) (Arunagiri \& Jayakumar, 2020). Such wastes are made evident through the MUDAS system and recognized by Japanese manufacturing. In other words, something that does not add value to the final product becomes a type of waste, therefore, it must be reduced or eliminated to reduce the cost of production and increase the contribution margin.

The concept of lean manufacturing is commonly associated with the application of technical tools such as 5S, Kanban supermarkets, as well as Kaizen boards, Poka Yoke among others. This comparison is too simple and does not reflect the different concepts and techniques that the Toyota Production System (TPS) relies on to run a complex product manufacturing system and why the whole "toolbox" is needed. (Rüttimann \& Stöckli, 2016)

Thus, the Toyota Production System gives special emphasis to the production system, reducing the delivery time of the process (Process lead time) and the toolbox constitutes the structure under which the maximization of production will be achieved, seeking to guarantee quality at the work station. TPS, through careful observation and evaluation determines the best way to eliminate any waste and optimize the process performance.

The MUDA constitutes an element for the optimization of the process that is complemented by the Mura (variation) and Muri (overload), that is, it smoothes the unevenness. In addition to the underlying tools (SMED, Heijunka-pitch) to create a smooth production schedule, as well as the simple technique to control the start of production (Kanban), TPS has also originated the continuous improvement approach (Kaizen). The search for perfection through the use of the "hidden" knowledge of the operators at the base, where production takes place (Gemba). (Rüttimann \& Stöckli, 2016)
A fundamental aspect in a production system is the management of supplies, this has different objectives, but its common base lies in the seven "Rights": (1) Product, (2) Quality, (3) Time, (4) Quantity, (5) Location, (6) People and (7) Cost, in the correct quantity and form; Traditionally, some authors only propose the use of the first 5, but the inclusion of the last 2 factors allows an adequate assessment of the system when considering an approach "lean". (Hofbauer G et al, 2012), (Helmold M. , 2013), cited by (Helmold \& Terry, 2017).

The above means that achieving a correct product requires compliance with customer requirements through specifications and with the correct quality, quantity, at the right time and location, considering the time constraints implicitly stated in the distribution with the support of trained operators. (Helmold \& Terry, 2017). A transformation of the production system to TPS is basically Womack's proposal (Womack \& Jones, 2003) which consists of the following (1) Identifying the flow of value, (2) Showing the flow of value and eliminating waste, (3) Transforming the flow of value by implementing flow in customer attraction, (4) Training people, (5) Striving for perfection. Thus, the challenge is constituted by the last three steps in which the system goes from being a PUSH system to a PULL system where production is driven by customer demand.

The Toyota house is credited to Taiichi Ohno's disciple, Fujio Cho, who developed the model for teaching TPS to suppliers. The model is cognitive in nature, structuring the components of the TPS. The two pillars on which the Toyota production system rest are oriented towards flow and quality, with support from Kaizen to reduce MUDA (Rüttimann \& Stöckli, 2016) (Rüttiman, 2018) (Liker, 2004).

A model that proposes the interaction of tools and stages through which the TPS is developed is proposed by (Rüttiman, 2018) in it, the goals, techniques and means are appreciated according to the level of complexity in manufacturing. The model first presents a single-product production system in which the goals consist of going to the Gemba with floor equipment and eliminating bottlenecks, having as ideal zero defects, equipment availability, reproducibility and optimization of work, as well as on-time delivery, through Balancing, Jidoka TPM, Standard Work, 5S and TAKT. 
Second, for a multiproduct system the goals lie in the area of leveling, flexibility and lay out, through Heijunka, SMED and Cellular Design. A third place is meant for Complex Products in which the goals reside in the use of cells and the logistics of decoupling through the creation of supermarkets, finally, the Supply Chain level in which the goals reside in Linked Cells, Production Activated and Just in Time through 7's Rights and Kan Ban systems.

To achieve survival, an organization needs to be competitive; it is through improving various aspects such as costs, quality, delivery service and flexibility. One of the approaches to achieve improvement is provided by Lean Manufacturing (Shah \& Ward, 2002). Implementing Lean Manufacturing generates observable benefits in various areas and sectors, therefore, Lean Manufacturing emerges as an approach that provides ways to improve quality, meet customer expectations, reduce every form of waste, improve the employees satisfaction and shorten delivery times (Braglia, Carmignani, \& Zammori, 2006) (Bakas, Govaert, \& Van Landeghem, 2011)

In the research from (Ghizoni Pereira \& Luz Tortorella, 2018) is noted that the application of Lean Manufacturing practices occurs within companies at the strategic, tactical and operational levels regardless of the size of the organization. The key is to identify the appropriate practices for the objective context in which the company finds itself. Among the most frequent practices found are: (1) Pull system, (2) Total Productive Maintenance, (3) Kaizen Continuous Improvement, (4) 5s, (5) Just in Time, (6) Cycle Time Reduction, (7) Total Quality Management , (8) Cellular Manufacturing, (9) Rapid Changes, (10) Staff Empowerment, (11) Value Stream Mapping, (12) Standardized Work, (13) Six Sigma, (14) Cross Functional Teams, (15) Statistical Process Control, (16) Visual Management, (17) Continuous Flow (18) Poka Yoke and (19) PDCA.

\section{Methodology to be developed}

\section{Object of study}

The object under study is the Final Assembly Area "Coaxials, Packaging and Others".

\section{Materials}

Digital stopwatch, Microsoft Excel, Camera, Flexometer, AutoCAD Software, Solidworks Software.

Procedure: (1) Analyze the production process. An 80-20 analysis was made to obtain the parts with the highest contribution in the area (High runners). (2) Determine average operating times. At this stage, the High runners' times were taken. (3) Balance. The Takt, the contribution percentage of each part and time weighted was calculated:

Weighted Time $=($ Contribution Percentage $)($ Operation Time $)$

The number of operators was obtained and subsequently the balancing was carried out assigning tasks to each operator. (5) Reduce change and preparation times. In this step, the SMED methodology was followed (Socconini, 2019) with the support of the Yamazumi tool; the new method was finally standardized. (6) Redistribute the area under study. The waste and areas of opportunity were detected, the redistribution proposals were designed where the families of parts, crossings, setbacks, areas of opportunity and waste found were considered.

\section{Results}

Result of the $80 / 20$ analysis, the High Runners of each product family were obtained with their average times shown in table 2 .

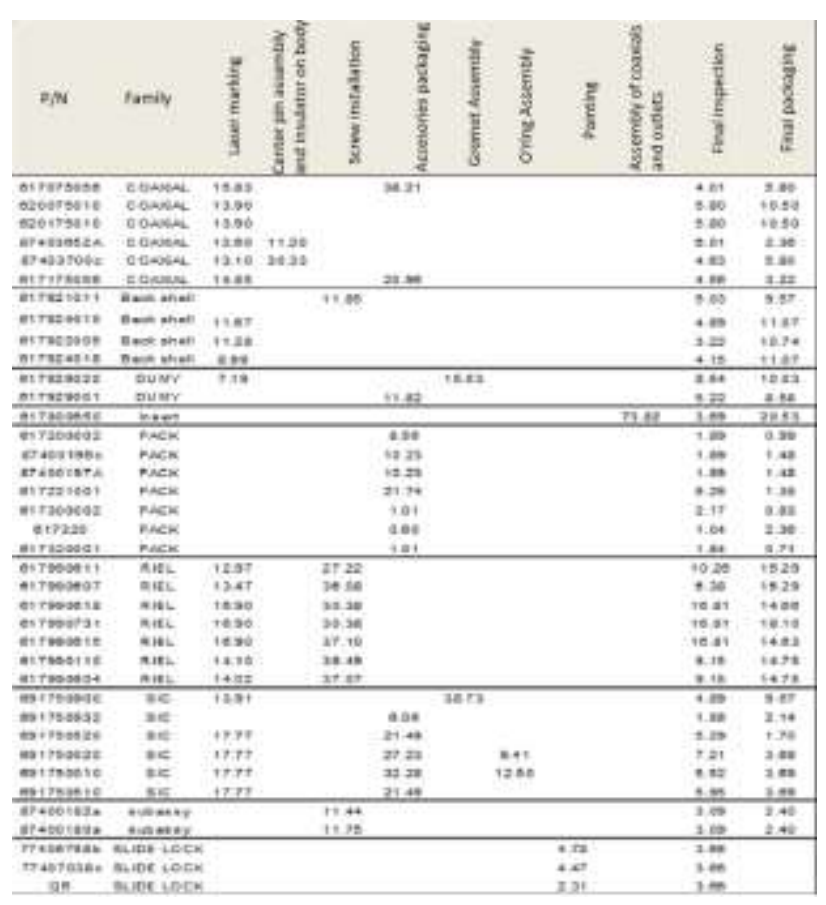

Table 2 Matrix of average operating times 
Once the average operating times were obtained, the weighted time calculations were made. The Takt Time obtained from turn 1 is as follows:

Tiempo Takt $=\frac{28739.7 \mathrm{seg}}{8274 \text { piezas }}=3.473495 \mathrm{Seg} /$ Piece

The calculation of operators per shift is seen in table 3.

\begin{tabular}{|c|c|c|}
\hline Operation & Time & $\begin{array}{l}\text { Operators } \\
\text { No. }\end{array}$ \\
\hline Laser marking & 1.386139 & 0.399062 \\
\hline $\begin{array}{l}\text { Center pin and insulator assembly on } \\
\text { body }\end{array}$ & 0.223958 & 0.064476 \\
\hline Screw installation & 1.048069 & 0.301733 \\
\hline Accessories packaging & 4.944549 & 1.423508 \\
\hline Gromet Assembly & 0.283489 & 0.081615 \\
\hline O'ring Assembly & 0.034272 & 0.009867 \\
\hline Painting & 1.134049 & 0.326487 \\
\hline Assembly of coaxial and outlets & 0.075834 & 0.021832 \\
\hline Final inspection & 3.239812 & 0.932724 \\
\hline Final Packaging & 2.285850 & 0.658083 \\
\hline Total & & 4.21939 \\
\hline
\end{tabular}

Table 3 No. of operators required for shift1

The calculation for shift 1 gave a result of 4.21939 operators and was adjusted to five, The activities assigned by operator are:

\begin{tabular}{|c|c|c|}
\hline Operator 1 & \multicolumn{2}{|c|}{ Laser marking, Accessories packaging } \\
\hline Operator 2 & \multicolumn{2}{|c|}{$\begin{array}{l}\text { Accessories packing, center pin assembly and body } \\
\text { insulator, screw installation, o'ring assembly, coaxial and } \\
\text { outlets assembly }\end{array}$} \\
\hline Operator 3 & \multicolumn{2}{|c|}{ Accessories packing, Gromet assembly, painted } \\
\hline Operator 4 & \multicolumn{2}{|c|}{ Final Inspection } \\
\hline Operator 5 & \multicolumn{2}{|c|}{ Final packaging, accessories packaging } \\
\hline Operator & Time & Takt Time \\
\hline Operator 1 & 2.81920 & 3.47350 \\
\hline Operator 2 & 2.81520 & 3.47350 \\
\hline Operator 3 & 2.85060 & 3.47350 \\
\hline Operator 4 & 3.23981 & 3.47350 \\
\hline Operator 5 & 2.93120 & 3.47350 \\
\hline
\end{tabular}

Table 4 Balancing operations for shift 1

In table 4, a margin for fluctuation of 0.5 sec has been left in the total time assigned with respect to the Takt Time, this due to a possible increase in demand or variation of time in the process, the flexibility criterion was used, seeking that the operators are certified in different operations that are carried out in the area; lastly, it was considered not to assign operations to the final inspector because he has to fulfill other responsibilities. Due to these criteria and because of an engineering request, a support operator was assigned to each shift, in the case of shift 1 this is fully available for any operation.

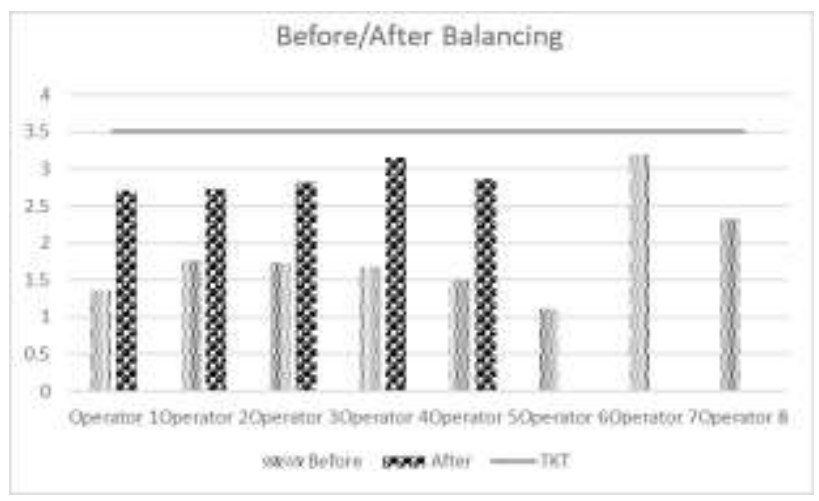

Figure 2 Operator before/after Line Balancing shift 1

The comparison of the balancing before and after went from 8 operators, which are 1.64 sec in average below the Takt allowing for leisure, to a more balanced assignment with 5 operators and a fluctuation margin of $0.54 \mathrm{sec}$.

To reduce Set-up times, a SMED was carried out in which the activities that could be performed while the machine was working were identified, as well as the activities that were could be eliminated because they did not add value and the internal activities that could be converted into parallel activities. Once the changes had been made, a reduction of the total time to 5.29 min was achieved, see table 5 .

\begin{tabular}{|l|r|r|r|}
\cline { 2 - 4 } & \multicolumn{1}{|c}{ Before } & \multicolumn{1}{c}{ After } & Saving \\
& (min) & (min) & \\
\hline Backshell & 11.18 & 5.38 & $52 \%$ \\
\hline Coaxial & 11.68 & 5.78 & $51 \%$ \\
\hline Dummy & 17.63 & 5.28 & $70 \%$ \\
\hline Rail & 16.35 & 5.2 & $68 \%$ \\
\hline Sic & 17.1 & 3.32 & $81 \%$ \\
\hline
\end{tabular}

Table 5 SMED results per family

In order to do the conversion of activities in parallel, Yamazumi was made, see figure 3.

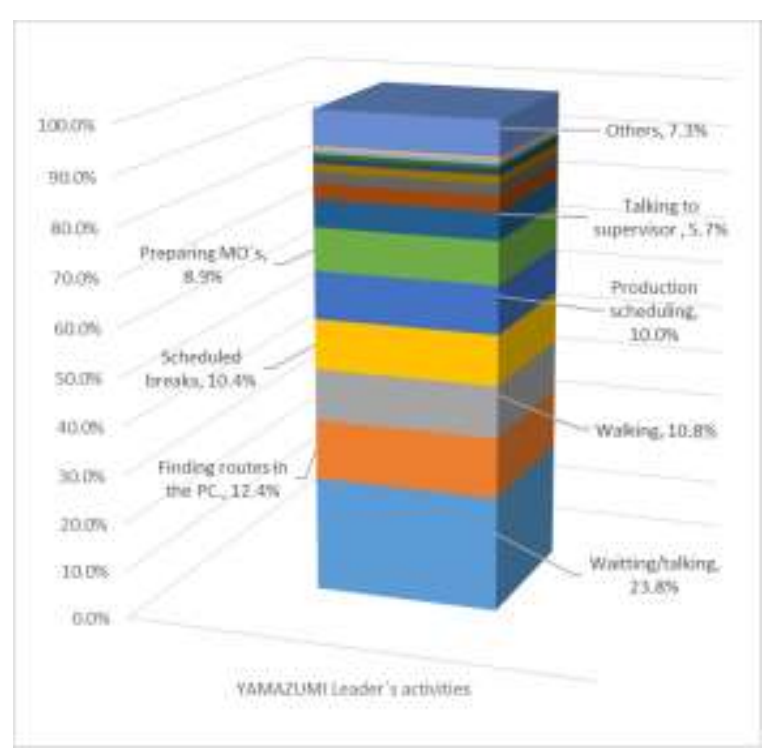

Figure 3 Area Leader Yamazumi

CANO-CARRASCO, Adolfo, FORNÉS-RIVERA, René Daniel, VÁSQUEZTORRES, María del Carmen and GUERRERO-PORTILLO, Arlene Amalia. Lean Manufacturing: Efficiency improvement application in multi-product area of the Aerospace Industry. Journal of Research and Development. 2021 
The ratio of percentages and activities that were developed throughout the 11-hour shift of the leading area, the highest percentage of time is in waiting and talks, therefore it was possible to assign activities converted in parallel in the set up.

For the redistribution of the area, the Spaghetti Diagram was used, the lack of process flow was detected, which resulted in 21 recurring crosses that occur mainly in the Laser Marking, Teak Print, Quality and Packaging operations, 10 Setbacks that put the operator and the product at risk due to congestion in the aisles, which caused collisions between them, see figure 5 .

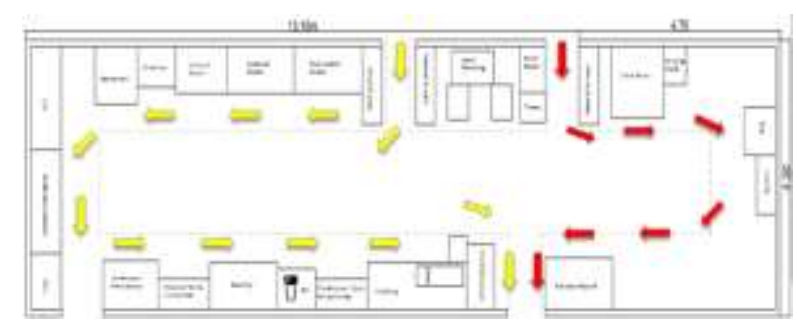

Figure 4 New distribution area and process flow

Completing the final packing table as it was redesigned, facilitated the relocation of the area; the unnecessary transportation and movements caused by the requirement of materials located in the racks were eliminated. In the new redistribution, two entrances and two exits were placed for safety reasons, as well as to ease the flow of materials. The area was relocated to enable the overseeing of the engineering supervisor, which results in greater control of the operators. The achievements after completing this project are summarized in the following table 6 .

\begin{tabular}{|c|c|c|c|c|}
\hline \multicolumn{5}{|c|}{ Results matrix } \\
\hline Resource & Before & After & Saving & Increase \\
\hline Operators & 14 & 11 & $121 \%$ & \\
\hline Set up time (min) & 17 & 4.4 & $74 \%$ & \\
\hline Space m2 & 60 & 53.71 & $10 \%$ & \\
\hline Crosses & 21 & 0 & $100 \%$ & \\
\hline Setbacks & 10 & 0 & $100 \%$ & \\
\hline $\begin{array}{lll}\begin{array}{l}\text { Theoretical } \\
\text { Produced) }\end{array} & \text { Capacity } & \text { (Units } \\
\end{array}$ & 2017 & 2371 & & $17.57 \%$ \\
\hline Productivity & $109 \%$ & $125 \%$ & & $16 \%$ \\
\hline
\end{tabular}

Table 6 Results matrix

\section{Conclusion}

During the development of the project, eight documents were generated that were essential for the fulfillment of the objective:
(1) Matrix of Processes for the Identification of Product Families, (2) Matrix of Times for High Runners, (3) Matrix of Weighted Times for Balancing Workloads, (4) Balancing Operations for Shift 1 and 2, (5) SMED standardized Diagram, (6) SMED Staff Training, (7) Lay out with Process Flow and (8) Savings Matrix. With this result, the intervention of the Lean Manufacturing at the operative level is evident (Ghizoni Pereira \& Luz Tortorella, 2018) (Piña et al., 2018) and (Monge et al., 2013) when carrying out the practices described in this topic.

In the balancing, it was obtained that there were two more operators in shift 1 and one in shift 2, which were relocated to other areas of the company, with this the productivity of the area increased by $16 \%$ and generated savings of USD 21,000 per year, while the distribution of operations made operators more flexible. With the implementation of SMED in the laser marking machine at the beginning, the switching times were greater than what it was thought with a change time of $8 \mathrm{~min}$ on average, when analyzing the videos an average change time of 17 min was obtained, this is due to the fact that the times provided by the company did not count the kit revision time and from here we started to make a Yamazumi diagram for the leader of the area to see if he had the available time to support the set up activities.

A $74 \%$ decrease was achieved, which represents an increase in its capacity of $17.57 \%$ since the time available to produce increased. With the redistribution of the area, a reduction of $10 \%$ of the used space was obtained, this favored its relocation since the room used for this was smaller, this could be achieved through the redesign of the packing table which implied the elimination of two racks of components adapting the material to the operator's reach and optimizing the space of the table. In this redistribution, an adaptation was made to a "U" manufacturing cell which allowed a process flow eliminating crossings and setbacks in the process and transports detected in the SMED. The changes made produced greater productivity at the operator level due to the decrease in distractors by reducing the approach among workstations. 


\section{References}

Arunagiri, P., \& Jayakumar, V. (2020). Assesment of hypothetical correlation between the various critical factors for lean systems in automobile industries, Mater. Today Proc.

Bakas, O., Govaert, T., \& Van Landeghem, H. (2011). Challenges and success factors for implementation of lean manufacturing in European SMES. In 13th International conference on the Modern Information Technology in the Innovation Processes of the industria Entrprise Vol 1. Tapir Academic Press.

Braglia, M., Carmignani, G., \& Zammori, F. (2006). A new value stream mapping approach for complex production systems. International Journal of Production Research, 44, 18-19.

De la Madrid, C. E. (s/f). La industria Aeroespacial y el despegue de la productividad en México. Obtenido de Este articulo se elaboro con informacion de Aregional, INEGI, ProMéxico y Secretaría de Economía: http://www.revistacomercioexterior.com/articul o.php?id=54\&t=la-industria-

\#: :text=De\%20acuerdo\%20con\%20la\%20Aso ciaci $\%$ C3\%B3n,en $\% 20$ promedio $\% 205.3 \% 25 \%$ 20por\%20a\%C3\%B1o.

García-Alcaraz, J., Maldonado-Macías, A., \& Cortes-Robles, G. (2014). Lean Manufacturing in the Developing World. Methodology, Case Studies and Trends from Latin America. Switzerland: Springer International Publishing.

Ghizoni Pereira, L., \& Luz Tortorella, G. (2018). A Literature Review on Lean Manufacturing in Small Manufacturing Companies. Progress in lean manufacturing. En J. Paulo Davim (Ed)., Springer, 69-89.

Helmold, M. (2013). Establishing a best-practice model of supplier relationship management (SRM) in multinational companies in the European transportation industry. Berlin: Wissenschaftlicher Verlag.

Helmold, M., \& Terry, B. (2017). Global Sourcing and Supply Management Excellence in China. Procurement Guide for Supply Experts. Springer Science+Business Media Singapore.
Hofbauer G et al. (2012). Lieferantenmanagement. Die wertorientierte Gestaltung der Lieferbeziehung. Munich: Oldenbourg Verlag.

Liker, J. (2004). The Toyota Way: 14 Management Principles from the World's Greatest Manufacturer. United States of America: McGraw-Hill.

Manzouri, M., Ab-Rahman, M., Zain, C., \& Jamsari, E. (2014). Increasing Production and Eliminating Waste through Lean. sustainability, 6, 9179-9204.

Monge, C., Cruz, J., \& López, F. (2013). Impacto de la Manufactura Esbelta, Manufactura sustentable y Mejora Contínua en la Eficiencia Operacional y Responsabilidad Ambiental en México. información tecnológica, vol.24, n.4, 15-32.

Nallusamy, S. (2020). Execution of lean and Industria techniques for productivity enhancement in a manufactury industry, MATER. . Today Proc.

Piña Domínguez, R., León Balderrama, J., \& Preciado Rodríguez, J. (2018). Nivel de implementación de la manufactura esbelta en la industria maquiladora de Hermosillo y Guaymas-Empalme, Sonora. RECAI. Revista de estudios en Contaduria Administración e Informática., 36-51.

Rahman, N., Sharif, S. M., \& Esa, M. M. (2013). Lean Manufacturing Case study with Kanban System Implementario. Procedia Economics and Finance 7.

Rüttiman, B. (2018). Lean Compendium Introduction to Modern Manufacturing Theory. Zürich, Switzerland: Springer.

Rüttimann, ,. B. (2015). Von Lean zu Industrie 4.0 - eine Evolution? Von einer visiona ren Idee zum. Presentation held at: Fertigungstechnisches Kolloquium.

Rüttimann, B. G.; Stöckli, M. (2016). Going beyond triviality: The Toyota production system-lean Going beyond triviality: The Toyota production system-lean. J. Serv. Sci. Manag., 9, 140-149. 
Rüttimann, B., \& Stöckli, M. (2016). Production System-Lean Manufacturing beyond MUDA and Kaizen. Journal of Service Science and Management, 140-149.

Shah, R., \& Ward, P. (2002). Lean manufacturing: context, practice bundles and performance. Journal of Operations Management. Elsevier, 21, 129-149.

Socconini, L. (2019). Lean Manufacturing Paso a Paso. Barcelona: Alfaomega Marge.

Womack, J., \& Jones, D. (1990). The Machine that Changed the World: The Triumph of Lean Production. New York, U.S.A.: Rawson Macmillan.

Womack, J., \& Jones, D. (2003). Lean Thinking. New York: Free Press. 